\title{
The Importance of Consumption of the Epidermis in Malignant Melanoma and Correlation with Clinicopathological Prognostic Parameters
}

\author{
Malign Melanoma'da Epidermal Yapısal Değişikliklerin Önemi ve \\ Klinikopatolojik Prognostik Parametreler ile İlişkisi
}

\author{
Selda SEÇKIN' ${ }^{1}$ Elmas ÖZGÜN² \\ Department of Pathology, 'Ankara Numune Education and Research Hospital, ANKARA, TURKEY, ${ }^{2}$ M.H. Yozgat State Hospital, YOZGAT, TURKEY
}

\begin{abstract}
Objective: The aim of the study was to investigate the importance of consumption of the epidermis as an additional diagnostic criteria for malignant melanoma and to evaluate its relationship to clinicopathological findings.

Material and Method: The age, gender, localization of the lesion and the histopathological parameters such as tumor type, Breslow thickness, ulceration, Clark's level, mitosis $/ \mathrm{mm}^{2}$, lymphocytic infiltration were noted in 40 malignant melanoma cases. Consumption of the epidermis was evaluated in tumor sections. Consumption of the epidermis (COE) due to thinning of the epidermis and loss of rete ridges was noted as (+) or (-). Furthermore, COE was compared with clinical and histopathological parameters. The Shapiro Wilk and Logistic Regression tests were used for statistical analysis. The results were accepted as significant if the $\mathrm{p}$ value was $<0.05$.
\end{abstract}

Results: COE was detected in $60 \%$ (24/40) of malignant melanoma cases. A positive correlation was present between COE and head and neck localization $(\mathrm{p}=0,698)$, superficial spreading melanoma $(\mathrm{p}=0,341)$, ulceration $(\mathrm{p}=0,097)$ and brisk lymphocytic infiltration $(p=0,200)$ but the results were not statistically significant. COE was frequently detected in males but the difference was not statistically significant $(\mathrm{p}=0.796$ ). There was no correlation or significant statistical association between $\mathrm{COE}$ and age, Breslow thickness, Clark's level or the mitotic index.

Conclusion: The detection of COE in most of the patients suggests that COE could be a histopathological criterion in the diagnosis of malignant melanoma. The frequent association between COE and the presence of ulceration could also direct attention to COE as regards prognostic importance.

Key Words: Epidermis, Melanoma, Prognosis

\section{ÖZ}

Amaç: $\mathrm{Bu}$ çalışmanın amacı, epidermal yapısal değişikliklerin malign melanom için ek tanı kriteri olarak değerini araştırmak ve klinikopatolojik bulgular ile ilişkisini değerlendirmektir.

Gereç ve Yöntem: Kırk malign melanom olgusunda klinik olarak yaş, cinsiyet, lokalizasyon; histopatolojik olarak tümör tipi, Breslow kalınlığ , ülserasyon, Clark düzeyi, mitoz/ $\mathrm{mm}^{2}$, lenfositik infiltrasyon değerlendirildi. Tümör dokusunda epidermal yapısal değişikliklerin varlığı araştırıldı. Epidermal yapısal değişiklikler, epidermisteki incelme ve retelerin kaybına göre (+) ya da (-) olarak kaydedildi. Ayrıca epidermal yapısal değișiklikler, klinik ve histopatolojik parametrelerle karşılaştırıldı. İstatistiksel çalışmada Shapiro Wilk ve Tek Değişkenli Lojistik Regresyon testleri kullanıldı. $\mathrm{p}<0,05$ için sonuçlar istatistiksel olarak anlamlı kabul edildi.

Bulgular: Epidermal yapısal değişiklikler malign melanom olgularının \%60'inda (24/40) mevcuttu. Epidermal yapısal değişiklikler ile başboyun yerleşimi $(\mathrm{p}=0,698)$, yüzeyel yayllan tümör tipi $(\mathrm{p}=0,341)$, ülserasyon varlığı $(\mathrm{p}=0,097)$ ve şiddetli lenfositik infiltrasyon $(\mathrm{p}=0,200)$ arasında pozitif korelasyon vardı. Ancak istatistiksel olarak anlamlı değildi. Epidermal yapısal değişiklikler erkeklerde kadınlara göre daha sık olarak izlendi, ancak aradaki fark istatistiksel olarak anlamlı bulunmadı ( $\mathrm{p}=0,796)$. Epidermal yapısal değişiklikler ile yaş, Breslow kalınlığı, Clark düzeyi ve mitoz sayısı arasında herhangi bir korelasyon veya anlamlı istatistiksel birliktelik saptanmadı.

Sonuç: Epidermal yapısal değişikliklerin olguların çoğunda saptanmış olması, malign melanom tanısında epidermal yapısal değişikliklerin bir histopatolojik kriter olabileceğini düşündürmektedir. Ayrıca epidermal yapısal değişikliklerin, ülserasyon varlığı ile olan sık birlikteliği, kötü prognostik gösterge olabilirliği açısından dikkat çekicidir.

Anahtar Sözcükler: Epidermis, Melanom, Prognoz

Correspondence: Elmas ÖZGÜN

Department of Pathology, M.H. Yozgat State Hospital, YOZGAT, TURKEY

E-mail: elmasozgun@yahoo.com.tr Phone: +90 5055885773 


\section{INTRODUCTION}

The term consumption of epidermis (COE) has recentlybeen used to indicate the epidermal structural changes associated with malignant melanoma (MM) (1-3). COE defines the thinning of the epidermis and loss of the retes neighboring the melanocyte group due to the decreased basal and suprabasal layers in the epidermis. This can be accompanied by squamous change of the basal layer and cleft formation between the epidermis and dermis $(4,5)$. The aim of this study was to investigate COE as an additional diagnostic criterion for MM and to evaluate its association with some clinical findings and histopathological parameters.

\section{MATERIAL and METHOD}

We investigated 43 cases diagnosed with malignant melanoma in this study. Three cases were excluded because of intensive ulceration in the tumor tissue. The age, gender and tumor localization (head-neck, extremity, body) were recorded. However, no information was found in the records on the age of 2 patients. The hematoxylin-eosin sections were evaluated for all cases. The histopathological tumor type [acral lentiginous melanoma (ALM), lentigo maligna (LM)/lentigo maligna melanoma (LMM), nodular melanoma (NM) or superficial spreading melanoma (SSM)], Breslow thickness, ulceration, Clark level, mitosis/ $\mathrm{mm}^{2}$, and lymphocytic infiltration (none, mild, severe) were recorded. (Table I).

The presence of COE in the tumor tissue was investigated. COE was recorded as (+) or (-) depending on epidermal thinning and rete loss. COE was also compared with clinical and histopathological parameters.

Data analysis was performed with the "SPSS for Windows 11.5" package software. The Shapiro-Wilk test was used to determine whether continuous variables had a normal distribution. Descriptive statistics were age, Clark level, number of mitoses and Breslow thickness and were presented as median (minimum-maximum) while the nominal variables were presented as number of cases and $\%$. The statistical significance of any effect of the factors thought to be possibly effective on COE positivity was evaluated with the Univariate Logistic Regression Analysis. The Odds Ratios and 95\% confidence intervals were also calculated. The values were considered statistically significant when $\mathrm{p}<0.05$.

\section{RESULTS}

The age range of the subjects was between 36 and 84 years, and $52.5 \%$ were male. Tumors located in the headneck and the extremities were equal in number while the most common tumor type was SSM at $40 \%$. The Breslow thickness of the cases was $0-16 \mathrm{~mm}$ and the number of mitoses $0-38 / \mathrm{mm}^{2}$. Ulceration was present in $27.5 \%$ and the anatomic invasion depth was Clark level III or IV in the majority (62.5\%) (Table II). COE was found in 60\% (24/40) of all MM cases (Figure 1). Basal layer squamous changes accompanied the COE in $41.7 \%(10 / 24)$ (Figure 2), and cleft formation between the epidermis and dermis in $75 \%$ (18/24) (Figure 3).

There was a positive correlation between COE and headneck localization $(\mathrm{p}=0.698)$, superficial spreading tumor type $(\mathrm{p}=0.341)$, the presence of ulceration $(\mathrm{p}=0.097)$ and marked lymphocytic infiltration $(\mathrm{p}=0.200)$. The incidence of

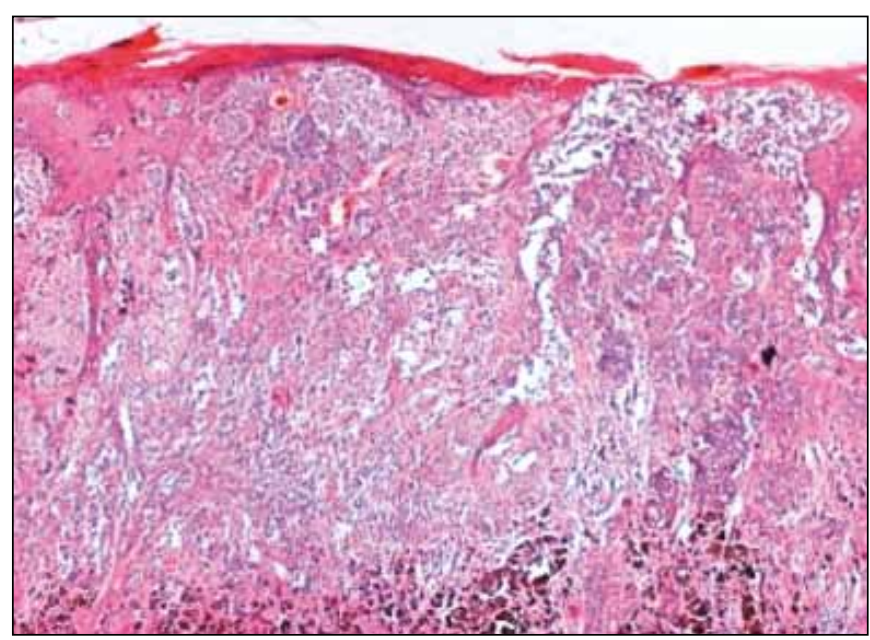

Figure 1: Malignant melanoma with deep dense pigmentation and pagetoid spread showing epidermal structural changes consisting of marked rete loss and epidermal thinning (H\&E; x40).

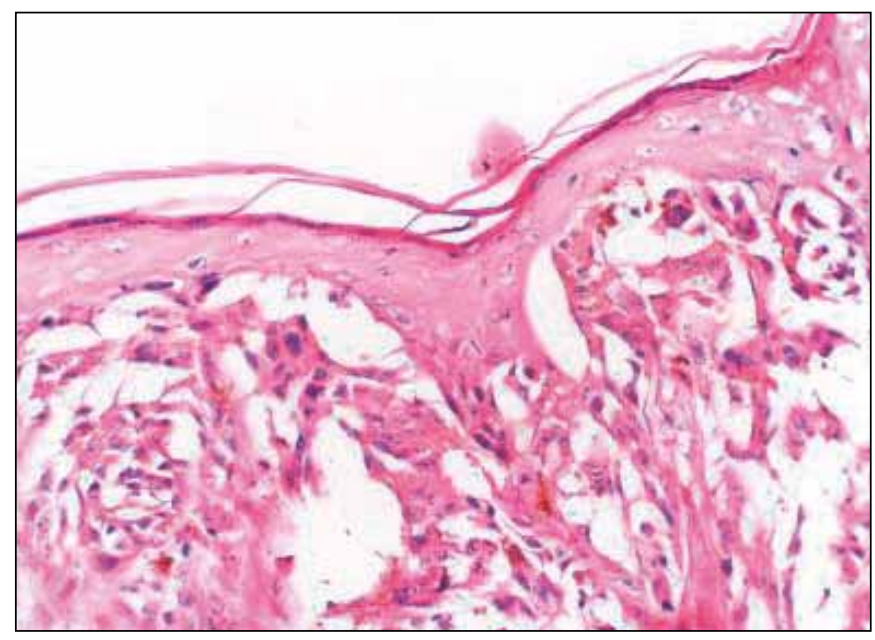

Figure 2: Malignant melanoma with epidermal thinning and cleft formation together with squamization in the basal layer $(\mathrm{H} \& \mathrm{E}$; $\mathrm{x} 200)$. 
Table I: Clinicopathological features of the cases

\begin{tabular}{|c|c|c|c|c|c|c|c|c|c|c|}
\hline No & Age & Gender & Localization & $\begin{array}{l}\text { Tm } \\
\text { type }\end{array}$ & $\begin{array}{c}\text { Breslow } \\
\text { thickness } \\
(\mathrm{mm})\end{array}$ & Ulceration & $\begin{array}{l}\text { Clark } \\
\text { level }\end{array}$ & Mitosis $/ \mathrm{mm}^{2}$ & $\begin{array}{l}\text { Lymphocytic } \\
\text { infiltration }\end{array}$ & $\mathrm{COE}$ \\
\hline 1 & 61 & $M$ & extremity & SSM & 3.8 & - & IV & 3 & mild & + \\
\hline 2 & 64 & $\mathrm{M}$ & head-neck & $\mathrm{NM}$ & 3 & - & III & 0 & mild & + \\
\hline 3 & 74 & $\mathrm{~F}$ & head-neck & $\mathrm{NM}$ & 1.5 & - & III & 9 & absent & + \\
\hline 4 & 64 & $\mathrm{~F}$ & extremity & SSM & 4 & + & IV & 4 & absent & + \\
\hline 5 & 36 & $\mathrm{M}$ & head-neck & SSM & 7.4 & + & $\mathrm{V}$ & 8 & severe & + \\
\hline 6 & 45 & $M$ & extremity & NM & 3.75 & - & III & 11 & mild & + \\
\hline 7 & 43 & $\mathrm{~F}$ & extremity & SSM & 2.5 & - & III & 9 & absent & + \\
\hline 8 & 45 & $\mathrm{M}$ & extremity & $\mathrm{NM}$ & 16 & - & $\mathrm{V}$ & 21 & absent & - \\
\hline 9 & 68 & $\mathrm{~F}$ & extremity & LMM & 0.55 & - & II & 1 & absent & - \\
\hline 10 & 60 & $M$ & extremity & SSM & 4 & + & IV & 15 & mild & - \\
\hline 11 & 50 & $\mathrm{M}$ & extremity & ALM & 2.7 & + & $\mathrm{V}$ & 4 & mild & - \\
\hline 12 & 75 & $\mathrm{~F}$ & head-neck & $\mathrm{NM}$ & 1 & - & $\mathrm{V}$ & 8 & mild & - \\
\hline 13 & 74 & $\mathrm{M}$ & head-neck & SSM & 0.9 & - & III & 4 & mild & + \\
\hline 14 & 77 & $\mathrm{~F}$ & extremity & SSM & 1.35 & - & III & 1 & mild & + \\
\hline 15 & 52 & $\mathrm{M}$ & head-neck & LMM & 4 & - & IV & 38 & absent & - \\
\hline 16 & 49 & $M$ & extremity & ALM & 6 & + & IV & 11 & absent & + \\
\hline 17 & 82 & $\mathrm{~F}$ & head-neck & NM & 4.5 & + & $\mathrm{V}$ & 22 & absent & + \\
\hline 18 & 82 & $\mathrm{~F}$ & head-neck & $\mathrm{NM}$ & 3.5 & - & $\mathrm{V}$ & 25 & severe & - \\
\hline 19 & 59 & $\mathrm{~F}$ & extremity & ALM & 0.85 & - & III & 0 & absent & - \\
\hline 20 & & $\mathrm{~F}$ & head-neck & SSM & 4.5 & - & $\mathrm{V}$ & 4 & absent & + \\
\hline 21 & 37 & $M$ & body & SSM & 3 & - & IV & 13 & severe & + \\
\hline 22 & & $\mathrm{M}$ & extremity & SSM & 1 & - & II & 2 & absent & - \\
\hline 23 & 75 & $\mathrm{M}$ & head-neck & SSM & 0.35 & - & II & 0 & mild & + \\
\hline 24 & 68 & $M$ & extremity & $\mathrm{NM}$ & 8 & - & $\mathrm{V}$ & 6 & absent & - \\
\hline 25 & 60 & $\mathrm{~F}$ & extremity & SSM & 2.3 & - & IV & 3 & absent & - \\
\hline 26 & 38 & $\mathrm{~F}$ & extremity & NM & 4.7 & + & $\mathrm{V}$ & 8 & absent & + \\
\hline 27 & 76 & $\mathrm{M}$ & head-neck & SSM & 6.5 & - & IV & 13 & mild & + \\
\hline 28 & 59 & $\mathrm{~F}$ & head-neck & SSM & 1 & - & IV & 11 & mild & - \\
\hline 29 & 65 & $M$ & head-neck & $\mathrm{NM}$ & 14.6 & - & $\mathrm{V}$ & 19 & mild & + \\
\hline 30 & 66 & $\mathrm{~F}$ & head-neck & LM & 0 & - & I & 0 & severe & + \\
\hline 31 & 61 & $\mathrm{~F}$ & head-neck & LMM & 0.6 & - & II & 1 & severe & - \\
\hline 32 & 77 & M & body & SSM & 3.13 & + & IV & 5 & mild & + \\
\hline 33 & 55 & $\mathrm{~F}$ & extremity & SSM & 1.3 & - & III & 5 & severe & + \\
\hline 34 & 75 & $M$ & head-neck & $\mathrm{NM}$ & 0.5 & - & IV & 12 & absent & + \\
\hline 35 & 71 & $M$ & head-neck & LMM & 0.5 & - & II & 0 & mild & - \\
\hline 36 & 57 & $\mathrm{~F}$ & extremity & ALM & 3 & + & IV & 1 & mild & + \\
\hline 37 & 81 & $\mathrm{M}$ & head-neck & $\mathrm{NM}$ & 8 & + & $\mathrm{V}$ & 3 & severe & + \\
\hline 38 & 71 & $\mathrm{~F}$ & head-neck & LM & 0 & - & $\mathrm{I}$ & 0 & absent & - \\
\hline 39 & 84 & $\mathrm{~F}$ & extremity & $\mathrm{NM}$ & 5 & + & IV & 6 & severe & + \\
\hline 40 & 43 & $\mathrm{M}$ & extremity & $\mathrm{NM}$ & 11 & - & $\mathrm{V}$ & 13 & absent & - \\
\hline
\end{tabular}

ALM; acral lentiginous melanoma, LM; lentigo maligna, LMM; lentigo maligna melanoma, NM; nodular melanoma, SSM; superficial spreading melanoma, COE; consumption of epidermis, Tm; tumor. 


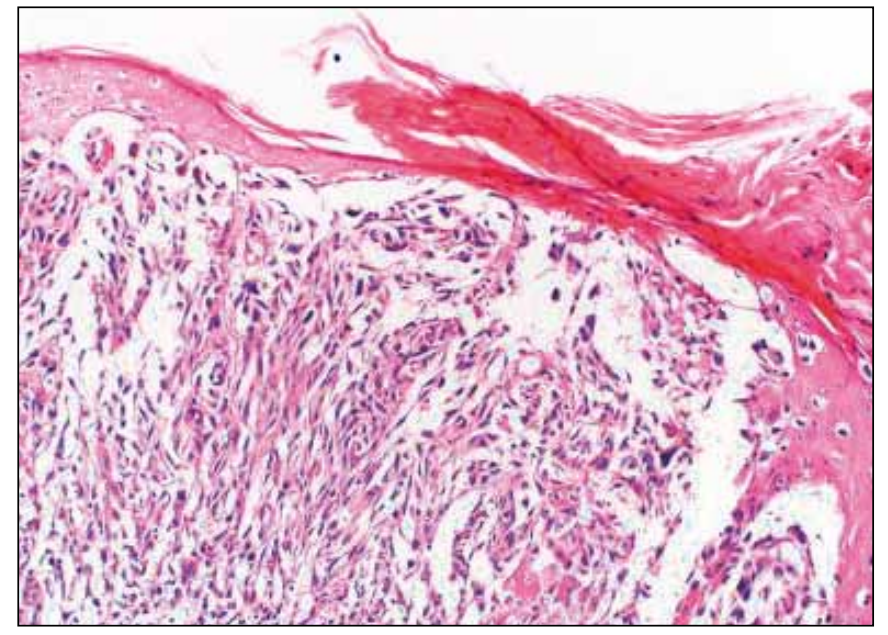

Figure 3: Marked epidermal structural changes consisting of epidermal thinning and rete loss accompanied by epidermal cleft formation (H\&E; x100).
$\mathrm{COE}$ was 1.3 times higher in head-neck tumors compared to those located on the extremities-body. The COE incidence was increased 3 times in SSM and 1.8 times in NM compared to ALM. The incidence of COE in the tumor was 4.2 times higher in the presence of ulceration. $\mathrm{COE}$ was also 3.4 times more common in tumors with marked lymphocytic infiltration and 2.3 times more common in tumors with mild lymphocytic infiltration compared to tumor with no lymphocytic infiltration. However, these findings were not statistically significant (Table III).

Epidermal structural changes were 1.2 times more common in males than females but the difference was not statistically significant $(p=0.796)$. No correlation or statistically significant relationship was found between COE and age, Clark level, Breslow thickness and number of mitoses (Table III).

Table II: Distribution of the clinicopathological features of the cases

\begin{tabular}{|ll|c|}
\hline & Features & Number (\%) \\
\hline Age & Median (min.-max.) & $64(36-84)$ \\
\hline Gender & Female & $19(47.5)$ \\
& Male & $21(52.5)$ \\
\hline Localization & Head-neck & $19(47.5)$ \\
& Extremity & $19(47.5)$ \\
& Body & $2(5.0)$ \\
\hline Tumor type & Acral lentiginous melanoma & $4(10.0)$ \\
& Lentigo maligna / Lentigo maligna melanoma & $6(15.0)$ \\
& Nodular melanoma & $14(35.0)$ \\
& Superficial spreading melanoma & $16(40.0)$ \\
\hline Breslow thickness (mm) & Median (min.-max.) & $3.0(0.0-16.0)$ \\
\hline Ulceration & $(+)$ & $11(27.5)$ \\
& $(-)$ & $29(72.5)$ \\
\hline Clark level & I & $2(5.0)$ \\
& II & $5(12.5)$ \\
& III & $8(20.0)$ \\
& IV & $13(32.5)$ \\
& V & $12(30.0)$ \\
\hline Mitosis (mm ${ }^{2}$ ) & Median (min.-max.) & $5.5(0.0-38.0)$ \\
\hline Lymphocytic infiltration & Absent & $17(42.5)$ \\
& Mild & $15(37.5)$ \\
& Severe & $8(20.0)$ \\
\hline COE & $(+)$ & $24(60.0)$ \\
& $(-)$ & $16(40.0)$ \\
\hline
\end{tabular}

COE, consumption of epidermis; min, minimum; max, maximum. 
Table III: Relationship between clinicopathological features and COE

\begin{tabular}{|c|c|c|c|c|c|}
\hline & & $\begin{array}{c}\operatorname{COE}(+) \\
n=24(60 \%)\end{array}$ & $\begin{array}{c}\operatorname{COE}(-) \\
n=16(40 \%)\end{array}$ & $\begin{array}{c}\text { OR } \\
(95 \% \mathrm{CI})\end{array}$ & $\mathbf{p}$ \\
\hline Age & Median (min.-max.) & $65(36-84)$ & $60(43-82)$ & $1.0(0.9-1.1)$ & 0.713 \\
\hline Gender & $\begin{array}{l}\text { Female } \\
\text { Male }\end{array}$ & $\begin{array}{l}11(45.8 \%) \\
13(54.2 \%)\end{array}$ & $\begin{array}{l}8(50.0 \%) \\
8(50.0 \%) \\
\end{array}$ & $\begin{array}{l}1.0 \\
1.2(0.3-4.2)\end{array}$ & 0.796 \\
\hline Localization & $\begin{array}{l}\text { Extremity-Body } \\
\text { Head-neck }\end{array}$ & $\begin{array}{l}12(50.0 \%) \\
12(50.0 \%)\end{array}$ & $\begin{array}{l}9(56.3 \%) \\
7(43.8 \%)\end{array}$ & $\begin{array}{l}1.0 \\
1.3(0.4-4.6)\end{array}$ & 0.69 \\
\hline Tumor type & $\begin{array}{l}\text { Acral lentiginous melanoma } \\
\text { Lentigo maligna / } \\
\text { Lentigo maligna melanoma } \\
\text { Nodular melanoma } \\
\text { Superficial spreading melanoma }\end{array}$ & $\begin{array}{c}2(8.3 \%) \\
1(4.2 \%) \\
9(37.5 \%) \\
12(50.0 \%) \\
\end{array}$ & $\begin{array}{l}2(12.5 \%) \\
5(31.3 \%) \\
5(31.3 \%) \\
4(25.0 \%)\end{array}$ & $\begin{array}{l}1.0 \\
0.2(0.0-3.7) \\
1.8(0.2-16.9) \\
3.0(0.3-28.8)\end{array}$ & $\begin{array}{l}0.278 \\
0.608 \\
0.341 \\
\end{array}$ \\
\hline Breslow thickness (mm) & Median (min.-max.) & $3.4(0.0-14.6)$ & $1.7(0.0-16.0)$ & $1.0(0.9-1.2)$ & 0.783 \\
\hline Ulceration & $\begin{array}{l}(-) \\
(+) \\
\end{array}$ & $\begin{array}{r}15(62.5 \%) \\
9(37.5 \%) \\
\end{array}$ & $\begin{array}{r}14(87.5 \%) \\
2(12.5 \%) \\
\end{array}$ & $\begin{array}{l}1.0 \\
4.2(0.8-23.0) \\
\end{array}$ & 0.097 \\
\hline Clark level & Median (min.-max.) & IV $(\mathrm{I}-\mathrm{V})$ & IV $(\mathrm{I}-\mathrm{V})$ & $1.1(0.6-1.9)$ & 0.740 \\
\hline Mitosis $\left(\mathbf{m m}^{2}\right)$ & Median (min.-max.) & $5.5(0-22)$ & $5(0-38)$ & $1.1(0.9-1.1)$ & 0.424 \\
\hline Lymphocytic infiltration & $\begin{array}{l}\text { none } \\
\text { mild } \\
\text { severe }\end{array}$ & $\begin{array}{r}8(33.3 \%) \\
10(41.7 \%) \\
6(25.0 \%)\end{array}$ & $\begin{array}{l}9(56.3 \%) \\
5(31.3 \%) \\
2(12.5 \%)\end{array}$ & $\begin{array}{l}1.0 \\
2.3(0.5-9.5) \\
3.8(0.5-21.7)\end{array}$ & $\begin{array}{l}0.268 \\
0.200\end{array}$ \\
\hline
\end{tabular}

COE; consumption of epidermis, min; minimum, max; maximum, CI; confidence interval

\section{DISCUSSION}

COE was present in 24 of 40 primary cutaneous malignant melanoma cases in this study (60\%). This result supports some other previous studies on the subject (3-5). The possible mechanisms responsible for the histological changes seen in COE are mechanophysical factors, immunological causes and molecular changes. The physical force of rapid tumor growth is said to contribute to the epidermal thinning $(1,4)$. However, there is no net tumor thickness range specified for $\mathrm{COE}$ (5). Immunological factors are also strongly considered as a mechanism for COE development. However, the presence of COE in all stages of malignant melanoma indicates that the primary role belongs to molecular changes. The absence of a correlation between Breslow thickness and COE in this study also indicates that no relationship is present between tumor growth and COE.

The changes in cadherin expression and degradation of the basal membrane with proteolytic enzymes facilitates $\mathrm{COE}$ development in malignant melanoma $(1,4)$. We found an increased COE incidence in the presence of ulceration in this study. This result is also consistent with previous studies and supports the use of $\mathrm{COE}$ as an unfavorable prognostic criterion. The epidermal thinning seen in COE due to this concurrence with ulceration is said to represent the early phase of ulceration (4).

In contrast to other studies, we found that COE was more common in male sex, tumors with a head-neck localization, in the superficial spreading tumor type and in the presence of severe lymphocytic infiltration. The MM survival rate is lower in males and the higher incidence of $\mathrm{COE}$ in the male sex may indicate its possible use an unfavorable prognostic criterion. The thickness at the time of detection of tumors in hard to detect areas is generally larger that those in easy to see areas. It is therefore said that tumors localized in the extremities have better survival rates than those localized in the head-neck or body (6). The presence of COE more commonly in tumors with a head-neck localization in this study can also indicate the possible use of COE as an unfavorable prognostic indicator.

A study aiming to evaluate the association between COE and the histological subtypes of malignant melanoma has reported the presence of $\mathrm{COE}$ in all histological subtypes 
with SSM the most common, as in our study (5). Another study has found the dermo-epidermal cleft formation that can accompany the COE most commonly in SSM and least commonly in LM (2). However, neither study found a significant relationship between the histological subtypes and $\mathrm{COE}$ and the dermo-epidermal cleft formation that can accompany $\mathrm{COE}$. We also found a higher incidence of $\mathrm{COE}$ in SSM compared to other histological subtypes.

A controversial issue regarding prognosis is whether brisk lymphocytic infiltration which tends to limit the increase in primary melanoma thickness has prognostic significance as generally accepted (7). However, Oble et al. have reported that the immune phenotype of the cells found in the infiltration may be as important as the density of the lymphocytic infiltration as regards the prognosis. Intratumoral $\mathrm{CD} 8+$ has a positive effect on survival while FoxP3+ regulatory $\mathrm{T}$ cells (Tregs) have a negative effect (8). Walters et al. have not found a significant relationship between the presence of COE and lymphocytic infiltration (4). We found a correlation between the presence of $\mathrm{COE}$ and lymphocytic infiltration density in this study but it was not statistically significant. These results may be due to the limited number of cases and the subjectivity of lymphocytic infiltration evaluation as a parameter and also the immunophenotypic characteristics of the lymphocytes.

We did not find any statistically significant correlation between $\mathrm{COE}$ and the prognostic parameters important for malignant melanoma such as Breslow thickness, number of mitoses and Clark level. It is interesting that while COE showed positive correlation with ulceration confirming that it may be used as an unfavorable prognostic criterion, it had no correlation with Breslow thickness, number of mitoses and Clark level. However, we believe this was due to the limited number of subjects.

We did not find a statistically significant correlation between the presence of $\mathrm{COE}$ and age as also reported in other studies. The prognosis is reported to be worse in the elderly in general. This is thought to be due to the more frequent occurrence of features indicating an unfavorable prognosis such as ulceration and increased tumor thickness in tumors seen in the elderly (9). We believe COE can be used as a histopathological criterion in MM diagnosis. The correlation of COE with ulceration, an important prognostic parameter in malignant melanoma, also indicates the importance of $\mathrm{COE}$ as an indicator of an unfavorable prognosis.

\section{REFERENCES}

1. Braun-Falco M: Cleft formation and consumption of the epidermis in cutaneous melanocytic lesions-reply. Hum Pathol 2006, 37: 247

2. Braun-Falco M, Friedrichson E, Ring J: Subepidermal cleft formation as a diagnostic marker for cutaneous malignant melanoma. Hum Pathol 2005, 36: 412-415

3. De Vries E, Bray F, Coebergh JW, Cerroni L, Ruiter DJ, Elder DE, Thompson JF, Barnhill RL, von Muijen GNP, Scolyer RA, LeBoit PE: Malignant melanoma: Introduction. In LeBoit PE, Burg G, Weedon D, Sarasin A. (Eds): World Health Organization Classification of Tumours. Pathology \& Genetics of Skin Tumours. Lyon, IARC Press, 2006, 52-65

4. Walters RF, Groben PA, Busam K, Millikan RC, Rabinovitz H, Cognetta A, Mihm MC Jr, Prieto VG, Googe PB, King R, Moore DT, Woosley J, Thomas NE: Consumption of the epidermis: a criterion in the differential diagnosis of melanoma and dysplastic nevi that is associated with increasing breslow depth and ulceration. Am J Dermatopathol 2007, 29: 527-533

5. Hantschke M, Bastian BC, LeBoit PE: Consumption of the epidermis: a diagnostic criterion for the differential diagnosis of melanoma and Spitz nevus. Am J Surg Pathol 2004, 28: 1621-1625

6. Weedon D: Lentigines, nevi and melanomas. In: Weedon D.(Ed): Skin Pathology. 3rd ed., China, Churchill Livingstone, 2010, 709-756

7. Elder DE, Elenitsas R, Murphy GF, Xu X: Benign pigmented lesions and malignant melanoma. In: Elder DE, Elenitsas R, Johnson BL, Murphy GF (eds): Lever's Histopathology of the Skin. 9th ed., Philadelphia, Lippincott Williams and Wilkins, 2005, 715-804

8. Oble DA, Loewe R, Yu P, Mihm MC Jr: Focus on TILs: prognostic significance of tumor infiltrating lymphocytes in human melanoma. Cancer Immun 2009, 9:3

9. McKee PH, Calonje E, Granter SR: Melanoma. In: McKee PH, Calonje E, Granter SR (eds): Pathology of the Skin with Clinical Correlations, 3th ed., China, Elsevier Mosby, 2005, 1309-1356 